Vol 2. No. 1, Januari 2022 P-ISSN : 2774-8030, e-ISSN : 2774-8030

\title{
PENGARUH KEPEMIMPINAN, MOTIVASI DAN LINGKUNGAN KERJA TERHADAP KINERJA KARYAWAN DI HOTEL D-MAX CONVENTION LOMBOK PRAYA NUSA TENGGARA BARAT
}

\author{
JUMAIDIN \\ Prodi Pariwisata Syariah, Fakultas Ekonomi dan Bisnis Islam,UIN Mataram \\ Email : didinkdarek@uinmataram.ac.id
}

\begin{abstract}
ABSTRAK
Tujuan dari penelitian ini adalah untuk mengetahui Pengaruh Kepemimpinan, Motivasi dan Lingkungan Kerja Terhadap Kinerja Karyawan Pada Hotel Daya Max Praya Lombok Convention Nusa Tenggara Barat. Data diperoleh melalui dokumentasi dan kuesioner. Sampel yang digunakan dalam penelitian sebanyak 90 responden. Hasil penelitian diharapkan dapat memberikan informasi yang berguna baik bagi manajemen hotel maupun staf hotel. Data yang diperoleh diolah dengan menggunakan analisis deskriptif dan analisis statistik kuantitatif. Analisis kuantitatif menggunakan regresi, namun sebelum dilakukan pengujian terlebih dahulu dilakukan pengujian validitas dan reliabilitas serta pengujian persyaratan. Hasil analisis menunjukkan bahwa terdapat pengaruh positif dan signifikan Kepemimpinan, Motivasi dan Lingkungan Kerja terhadap Kinerja Karyawan pada D-Max Praya Lombok Convention Hotel Nusa Tenggara Barat
\end{abstract}

Kata Kunci: Kepemimpinan, Motivasi, Lingkungan Kerja dan Kinerja Karyawan

\section{ABSTRACT}

The purpose of this study is to determine the The Effect of Leadership, Motivation and Work Environment on Employee Performance at the Daya Max Praya Lombok Convention Hotel in West Nusa Tenggara. Data were obtained through documentation and questionnaires. The sample used in the study of 90 respondents. Results are expected to provide useful information to both hotel management and hotel staff The data obtained were processed using descriptive analysis and quantitative statistical analysis. Quantitative analysis using regresi, but before the test is done first tested the validity and reliability testing as well as testing requirements. The analysis shows that there is positive and significant influence of Leadership, Motivation and Work Environment on Employee Performance at the D-Max Praya Lombok Convention Hotel in West Nusa Tenggara

Keywords: Leadership, Motivation, Work Environment and Employee Performance

\section{PENDAHULUAN}

Nusa Tenggara Barat merupakan provinsi yang mengalami perkembangan pariwisata yang sangat pesat terrbukti dengan meningkatnya kunjungan wisatawan baik domestik maupun mancanegara dari tahun ke tahun,nusa tenggara barat memiliki tempat-tempat objek wisata yang sangat indah dan menarik untuk dikunjungi, seperti beobjek wisata berapa air terjun dilombok dan sumabawa, pantai pink, tanjung ann, merese hill, senggigi pantai kuta yang sekarang dijadikanoleh pemerintah sebagai sepuluh destinasi baru bali di Indonesia yang didalamnya termasuk Mandalika Resort yang lokasinya berada di kabupaten Lombok Tengah bagian selatan.

Perhotelan di Nusa Tenggara Barat (NTB) ini dapat dibuktikan dengan program pemerintah yang akan membuat 10 destinasi baru bali dengan tujuan untuk kemajuan pariwisata Indonesia. Nusa Tenggara Barat sebagai salah satu daerah tujuan wisata yang mengalami perkembangan yang sangat pesat, hal ini dapat di lihat dengan semakin meningkatnya pembangunan sarana akomodasi usaha perhotelan yang menyediakan sarana dan prasarana seperti: kamar, restoran, tempat-tempat makan dan minum, serta jasa dan fasilitas lainya yang di butuhkan oleh para wisatawan terutama di kabupaten Lombok Tengah, Lombok Barat, Lombok Utara, oleh karena itu hotel harus memiliki sumber daya manusia yang pintar dan 
berkualitas yang akan mendorong kemajuan dari hotel-hotel tesebut. Dalam teori-teori manajemen sumber daya manusia menurut Dessler (2011) adalah kebijakan dan praktek didalam menggerakkan sumber daya manusia atau aspek-aspek terkait posisi manajemen didalam sumber daya manusia yang mencakup kegiatan perekrutan, penyaringan, pelatihan, pemberian penghargaan dan penilaian. Diharapkan dengan adanya sumber daya manusia yang berkualitas dan memiliki kepemimpinan serta budaya organisasi yang sesuai akan mempengaruhi kepuasan kerja bagi karyawan itu sendiri sehingga kinerja karyawan meningkat, serta tujuan yang ditetapkan oleh organisasi akan tercapai.

Hotel adalah sebagai salah satu bisnis yang bergerak dalam bidang usaha jasa pariwisata sudah tentu membutuhkan sumber daya manusia yang pintar dan teliti dalam segala hal untuk menjalankan roda bisnis dari hotel tersebut oleh karena itu sebagai salah satu unsur yang sangat menentukan keberhasilan suatu perusahaan. Hotel adalah sebuah organisasi layanan dimana jenis akomodasi yang mempergunakan sebagian atau keseluruhan bagian untuk menyediakan jasa pelayanan penginapan, penyedia makanan dan minuman serta jasa jasa lainnya bagi masyarakat umum yang dikelola secara komersil (Haryono, 2015). Hotel terdiri atas departemen-departemen yang tidak bisa lepas atau terpisah antara satu departemen dengan departemen yang lainnya, departemen tersebut di antaranya: Front Office Departement, Food \& Beverage Departement, Housekeeping Departemen, Accounting Departement, Purchasing Departement, Engineering Departement, dan Human Resource Departement (HRD), sudah tentu sekali akan membutuhkan sumber daya manusia yang banyak untuk melayani para wisatawan domestik dan mancanegara, oleh karena itu sumber daya manusia sangat diperlukan untuk mengelola sumber daya manusia yang baik dan benar demi keberlanjutan hotel tersebut terutama di kawasan Nusa Tenggara Barat khususnya di daerah kabupaten Lombok Tengah di area kawasan ekonomi khusus (KEK) Mandalika.

Pengelolaan Sumber Daya Manusia (SDM) tidak terlepas dari faktor pegawai/staff yang diharapkan dapat berprestasi sebaik mungkin demi mencapai tujuan organisasi, pegawai merupakan aset utama organisasi dan mempunyai peran yang strategis didalam organisasi yaitu sebagai pemikir, perencana, dan pengendali aktifitas organisasi. Demi tercapainya tujuan organisasi, pegawai memerlukan motivasi untuk menghasilkan pekerja yang lebih baik. Melihat pentingnya pegawai dalam suatu organisasi, maka setiap pegawai diperlukan perhatian lebih serius terhadap tugas yang dikerjakan sehingga tujuan organisasi tercapai.

Menurut Nawawi (2008), "Motivasi berarti suatu kondisi yang mendorong atau menjadi penyebab seseorang untuk melakukan suatu perbuatan atau kegiatan, yang berlangsung secara sadar ". Motivasi yang rendah akan banyak menimbulkan gejala-gejala dari internal seperti : apresiasi kerja karyawan kurang diperhatikan, kebutuhan karyawan kurang diperhatikan, kurangnya bertanggung jawab karyawan, beban kerja yang tidak sesuai dengan gaji yang diterima, pembagian uang service yang berbeda-beda. Sedangkan eksternal seperti : memilih dalam bekerja, hubungan antar karyawan tidak harmonis, motivasi kerja masih kurang, peralatan keamanan dan keselamatan masih kurang.

Motivasi kerja Hotel D'max Convention Lombok sudah berjalan dengan baik, akan tetapi masih ada juga karyawan yang kurang memiliki motivasi kerja, hal ini dapat dibuktikan dengan, kurang maksimal dalam memberikan pelayanan pada saat bekerja sehingga menyebabkan tamu komplin, misalnya salah menulis pesanan tamu dan kurangdalam penegasan pesanan, miss komunikasi antar karyawan pada saat tamu melakukan pesanan, kurang dihargai hasil pekerjaan yang dilakukan oleh karyawan training misalnya dalam melayani tamu maupun pada saat memasak di dapur. Dari semua permasalahan diatas hal-hal seperti inilah yang menyebabkan motivasi kerja karyawan akan berkurang.

Dalam setiap pekerjaan, lingkungan kerja akan berpengaruh besar terhadap kinerja karyawan oleh karena itu lingkungan kerja yang baik secara otomatis akan menghasilkan keuntungan perusahaan dan juga akan menyejahterakan karyawannya. Lingkungan kerja yang kondusif akan memberikan rasa aman dan nyaman terhadap karyawan yang bekerja dan memungkinkan para karyawan untuk bekerja optimal. 
Kinerja merupakan perilaku nyata yang ditampilkan setiap orang sebagai prestasi kerja yang dihasilkan oleh karyawan sesuai dengan perannya dalam instansi. Manajemen hotel umumnya mendasarkan perencanaan tujuan yang hendak dicapai di masa depan dengan perilaku yang diharapkan dari keseluruhan personel dalam mewujudkan tujuan tersebut. Menurut Sugiyono (2009) faktor yang berpengaruh terhadap kinerja karyawan adalah kualitas pekerjaan, kuantitas pekerjaan, pengetahuan pekerjaan, kerjasama tim, kreatifitas, inovasi dan inisiatif.

\section{METODE PENELITIAN}

Pendekatan dalam penelitian adalah salah satu bagian dari keseluruhan proses penelitian. Pendekatan penelitian menjadi dasar penetapan desain atau desain penelitian, yang karenanya harus dipilih secara cermat. Penelitian ini menggunakan desain penelitian kuantitatif dengan pendekatan korelasional. Menurut Sukmadinata (2010) penelitian korelasional ditujukan untuk mengetahui hubungan antar variabel-variabel lain. Hubungan antara satu dengan beberapa variabel lain dinyatakan dengan besarnya koefisien korelasi dan keberartian (signifikansi) secara statistik. Pendekatan korelasi dilakukan dengan tujuan untk menemukan adanya pengaruh, kepemimpinan, motivasi dan lingkungan kerja terhadap kinerja karyawan serta seberapa erat tingkat pengaruhnya.

Desain penelitian ini menggunakan analisis regresi linear berganda, analisis ini bertujuan menerangkan akibat langsung dan tidak langsung variablel kepemimpinan, variabel motivasi kerja, variabel lingkungan kerja, sebagai variabel penyebab terhadap kinerja karyawan di Hotel D-Max Convention Lombok Praya Nusa Tenggara Barat

Desain penelitian dapat digambarkan sebagai berikut :

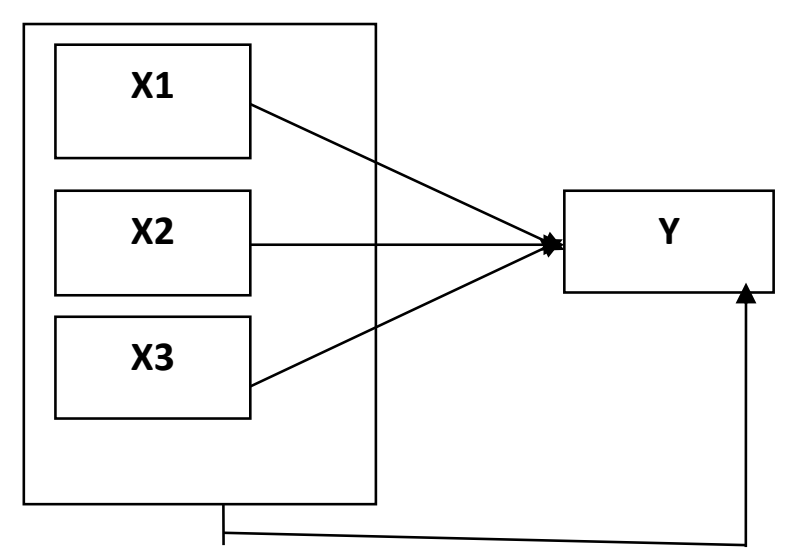

3.1 Gambara Desain Penelitian

Keterangan

$\mathrm{X} 1=$ Kepemimpinan

$\mathrm{X} 2=$ Motivasi Kerja

X3= Lingkungan Kerja

Y= Kinerja Karyawan

\section{HASIL DAN PEMBAHASAN}

\section{Hasil}

Hotel Dmax \& convention Lombok dibuka untuk umum pada tanggal 16 Februari 2016 dan Soft Opening 24 Desember 2015, Dmax hotel \& convention Lombok dikelola oleh PT. Jaya Cipta Hotel yang merupakan hotel Chain Nasional. Terletak di Jalan bypass BIL dan sangat dekat ke bandara Lombok. Memiliki hotel grup di Jakarta, Aceh dan Bali.sebagai direktur utama Bapak Ngadiman, Direktur Operasional Bapak Dedy dan General Manager Bapak Oscarios Marbun. Dmax hotel \& convention Lombok mempunyai visi menjadikan D'Hospitality Management sebagai pilihan tebaik dalam pengelolaan Industri hotel, restoran, apartment, rumah sakit, mall, entertainment dan town house sertago public dan misinya adalah memberikan layanan yang berkesan, tak terlupakan bagi pelanggan, keuntungan maksimal bagi pemilik dan pemegang saham serta memberikan kesejahteraan bagi pekerja.Dmax hotel \& convention Lombok memiliki 137 kamar, pada tahun 2019 sampai bulan desember jumlah SDM berjumlah 75 orang pekerja kontrak dan 15 orang pekerja daily worker. 


\section{Responden Berdasarkan Jenis Kelamin}

Tabel 1. Responden Berdasrkan Jenis Kelamin

\begin{tabular}{|r|l|c|c|}
\hline NO & \multicolumn{1}{|c|}{ Jenis Kelamin } & Frekuensi & $\%$ \\
\hline 1 & Laki-Laki & 71 & 78.88 \\
\hline 2 & Perempuan & 19 & 21.11 \\
\hline & Total & 90 & 100 \\
\hline
\end{tabular}

Sumber: Data Primer Yang Diolah 2019

Responden di dominasi oleh karyawan berjenis kelamin laki-laki dengan jumlah 71 orang atau $78.88 \%$ sedangkan responden berjenis kelamin perempuan berjumlah 19 orang atau $21.11 \%$ dari jumlah total.

\section{Responden Menurut Usia}

Berdasarkan usia, maka responden dapat ditabulasikan sebagai berikut:

Tabel 2. Responden Berdasarkan Usia

\begin{tabular}{|c|c|c|}
\hline Usia & Frekuensi & $\%$ \\
\hline $10-20$ & 3 & 3.33 \\
$21-30$ & 58 & 64.44 \\
$31-40$ & 21 & 23.33 \\
$41-50$ & 8 & 8.88 \\
\hline TOTAL & 90 & 100 \\
\hline
\end{tabular}

Sumber : data primer yang diolah 2019

Berdasarkan usia, sebagianbesar responden berusiaantara, kelompok $21 \mathrm{~s} / \mathrm{d} 30$ tahun 58 orang $(64,44 \%)$, selanjutnya disusun dengan kelompok usia $31 \mathrm{~s} / \mathrm{d} 40$ tahun sebanyak 21 orang (23.33\%), lalu kelompok usia $41 \mathrm{~s} / \mathrm{d} 50$ tahun dan kelompok usia $51 \mathrm{~s} / \mathrm{d} 60$ tahun masingmasing 8 orang $(8,88 \%)$ serta usia 10 s/d 20 tahun 3 orang $(3,33 \%)$.

\section{Responden Menurut Tingkat Pendidikan}

Berdasarkan tingkat pendidikan,maka responden dapat ditabulasikan sebagai berikut Tabel 3. Responden Berdasarkan Tingkat Pendidikan

\begin{tabular}{|c|r|c|c|}
\hline NO & TingkatPendidikan & Frekuensi & $\%$ \\
\hline 1 & SLTP & 1 & 1.11 \\
2 & SLTA & 47 & 52.22 \\
3 & D3/Sarjana & 42 & 46.66 \\
4 & Lain-Lain & 0 & 0 \\
\hline & TOTAL & 90 & 100 \\
\hline
\end{tabular}

Sumber: data primer yang diolah 2019

Berdasarkan pendidikanmaka bagian besar responden berpendidikan SLTA sebanyak 47 orang $(52.22 \%)$, selanjutnya berpendidikan D3/Sarjana sebanyak 42 orang $(46,66 \%)$, serta berpendidikan SLTP sebanyak 1 orang $(1,11 \%)$

\section{Responden Menurut Masa Kerja}

Berdasarkan masa kerja, maka responden dapat di tabulasikan sebagai berikut :

Tabel 4. Responden Berdasarkan Masa Kerja

\begin{tabular}{|c|c|c|}
\hline MASA KERJA & FREKUENSI & $\%$ \\
\hline $0-1$ & 24 & 26.66 \\
$1-2$ & 22 & 24.44 \\
$2-3$ & 41 & 45.55 \\
$3>$ & 3 & 3.33 \\
\hline TOTAL & 90 & 100 \\
\hline
\end{tabular}

Sumber:Data primer diolah 2019

Berdasarkan masa kerja, maka sebagian besar responden adalah dengan masa kerja $2 \mathrm{~s} / \mathrm{d}$ 3 tahun sebanyak 41 orang (45.55\%), disusul masa kerja 0 s/d 1 tahun sebanyak 24 orang 
(26,66\%), masa kerja $1 \mathrm{~s} / \mathrm{d} 2$ tahun sebanyak 22 orang (24,44\%), masa kerja 3 tahun lebih sebanyak 3 orang $(3.33 \%)$.

\section{Uji Reliabilitas}

Pengujian reliabilitas ini dilakukan dengan menghitung koefisien formula Cronbach Alpha, dengan kriteria sebagai berikut:

1. Apabila Alpha Cronbach $>0,60$, maka suatu variabel tersebut dinyatakan reliabel.

2. Apabila Alpha Cronbach $<0,60$, maka suatu variabel tersebut dinyatakan tidak reliabel. Adapun pengujian reliabilitas variabel kepemimpinan $\left(\mathrm{X}_{1}\right)$, Motivasi $\left(\mathrm{X}_{2}\right)$, lingkungan kerja $\left(\mathrm{X}_{3}\right)$ terhadap kinerja karyawan $(\mathrm{Y})$ di hotel D-max and Convention Lombok

\section{Tabel 5. Pengujian Reliabilitas}

\begin{tabular}{|c|l|c|c|c|}
\hline No & \multicolumn{1}{|c|}{ Variabel } & Alpha & Alpha Standar & Keterangan \\
\hline 1. & Kepemimpinan $\left(\mathrm{X}_{1}\right)$ & 0.752 & 0,60 & Reliabel \\
\hline 2. & Motivasi $\left(\mathrm{X}_{2}\right)$ & 0.752 & 0,60 & Reliabel \\
\hline 3. & Lingkungan kerja $\left(\mathrm{X}_{3}\right)$ & 0.751 & 0,60 & Reliabel \\
\hline 4. & Kinerja karyawan $(\mathrm{Y})$ & 0.752 & 0,60 & Reliabel \\
\hline
\end{tabular}

Sumber: Data Primer diolah, 2019

Berdasar Tabel 5 pengujian reliabilitas diatas, dapat diketahui bahwa semua variabel mempunyai nilai Alpha Cronbach> 0,60 sehingga dapat dikatakan bahwa semua konsep pengukur masing-masing variabel dari kuesioner adalah reliabel dan layak digunakan untuk penelitian.

\section{Hasil Analisis Regresi Linier Berganda}

Analisis regresi linier berganda dilakukan untuk mengetahui besarnya pengaruh variabel independen Kepemimpinan $\left(\mathrm{X}_{1}\right)$, Motivasi $\left(\mathrm{X}_{2}\right)$, lingkungan kerja $\left(\mathrm{X}_{3}\right)$ terhadap variabel dependen Kinerja Karyawan (Y). Rekapitulasi hasil analisis regresi linier berganda dengan bantuan program SPSS Ver.17 For Windows.:

Tabel 6. Analisis Regresi Linier Berganda

Coefficients $^{\mathrm{a}}$

\begin{tabular}{|c|c|c|c|c|c|}
\hline \multirow[b]{2}{*}{ Model } & \multicolumn{2}{|c|}{ Unstandardized Coefficients } & \multirow{2}{*}{$\begin{array}{c}\begin{array}{c}\text { Standardized } \\
\text { Coefficients }\end{array} \\
\text { Beta }\end{array}$} & \multirow[b]{2}{*}{$\mathrm{t}$} & \multirow[b]{2}{*}{ Sig. } \\
\hline & $\mathrm{B}$ & Std. Error & & & \\
\hline $1 \quad$ (Constant) & 29.869 & 12.630 & & 2.489 & .015 \\
\hline $\mathrm{X} 1$ & .318 & .101 & .306 & 2.724 & .032 \\
\hline $\mathrm{X} 2$ & .271 & .102 & .239 & 2.600 & .006 \\
\hline $\mathrm{X} 3$ & .248 & .104 & .231 & 2.520 & .009 \\
\hline
\end{tabular}

a. Dependent Variable: Y

Berdasarkan Tabel diatas, maka persamaan regresi yang didapat adalah:

$Y=\beta_{1} X_{1}+\beta_{2} X_{2}+\beta_{3} X_{3}$

$Y=0,306 X_{1}+0,239 X_{2}+0,231 X_{3}$

Uji Anova (F-test)

Uji Anova atau uji $\mathrm{F}$ adalah uji statistik yang fungsinya untuk mengetahui apakah variabel independen kepemimpinan, motivasi dan lingkungan kerja, berpengaruh terhadap kinerja karyawan. Pengujian tersebut dapat dilakukan sebagai berikut 
Vol 2. No. 1, Januari 2022 P-ISSN : 2774-8030, e-ISSN : 2774-8030

Tabel 7. Uji F

ANOVA

\begin{tabular}{|rr|r|r|r|r|r|}
\hline Model & Sum of Squares & df & Mean Square & F & \multicolumn{1}{c|}{ Sig. } \\
\hline 1 & Regression & 1263.231 & 3 & 356.216 & 4.367 & $.004^{\mathrm{a}}$ \\
Residual & 6365.324 & 86 & 68.308 & & \\
Total & 7629.351 & 89 & & & \\
\hline
\end{tabular}

a. Predictors: (Constant), X3, X2, X1

b. Dependent Variable: Y

Berdasarkan Tabel 7 di atas menunjukan bahwa F hitung sebesar 4.367> F table df 389 sebanyak 2,11, dengan nilai signifikansi 0,004 < 0,05. Maka dapat dikatakan bahwa variabel, Kepemimpinan, Motivasi dan Lingkungan Kerja secara bersama-sama berpengaruh terhadap Kinerja Karyawan hotel D-max and convention Lombok Praya Nusa Tenggara Barat.

\section{Uji Koefisien Determinasi (Uji $\mathbf{R}^{2}$ )}

Uji koefisien determinasi atau adjusted $R$ square digunakan untuk mengetahui seberapa pengaruh variabel bebas (independent variabel) terhadap variabel terikat (dependent variabel). Pengujian tersebut dapat dilihat pada Tabel 4.13 sebagai berikut:

Tabel 8. Uji Koefisien Determinasi

Model Summary

\begin{tabular}{|r|r|r|r|r|}
\hline Model & \multicolumn{1}{|c|}{$\mathrm{R}$} & R Square & \multicolumn{1}{c|}{$\begin{array}{c}\text { Adjusted R } \\
\text { Square }\end{array}$} & Std. Error of the Estimate \\
\hline 1 & $.631^{\mathrm{a}}$ & .532 & .501 & 6.64712 \\
\hline
\end{tabular}

a. Predictors: (Constant), X3, X2, X1

Berdasarkan hasil perhitungan estimasi regresi diperoleh nilai koefisien determinasi (Adjusted $R$ square) sebesar 0.501 artinya $50.1 \%$ perubahan pada variabel dependen kinerja karyawan $(\mathrm{Y})$ dapat dijelaskan oleh perubahan dalam variabel independen, Kepemimpinan, Motivasi Dan Lingkungan Kerja Sedangkan sisanya sebesar $49.9 \%$ diterangkan oleh variabel lain yang tidak diajukan atau dijelaskan dalam model penelitian ini.

Uji t ( pengaruh parsial )

Uji parsial digunakan untuk menguji hipotesis adanya pengaruh kepemimpinan, motivasi dan lingkungan kerja terhadap kinerja karyawan secara sendiri-sendiri, dengan taraf signifikansi $\alpha=0,05$. Berdasarkan pengolahan data, diperoleh hasil sebagai berikut:

\section{Tabel 9. Uji Hipotesis}

Coefficients $^{\mathbf{a}}$

\begin{tabular}{|c|c|c|c|c|c|}
\hline \multirow[b]{2}{*}{ Model } & \multicolumn{2}{|c|}{ Unstandardized Coefficients } & \multirow{2}{*}{$\begin{array}{c}\text { Standardized } \\
\text { Coefficients }\end{array}$} & \multirow[b]{2}{*}{$\mathrm{t}$} & \multirow[b]{2}{*}{ Sig. } \\
\hline & $\mathrm{B}$ & Std. Error & & & \\
\hline $1 \quad$ (Constant) & 29.869 & 12.630 & & 2.489 & .015 \\
\hline $\mathrm{X} 1$ & .318 & .101 & .306 & 2.724 & .032 \\
\hline $\mathrm{X} 2$ & .271 & .102 & .239 & 2.600 & .006 \\
\hline $\mathrm{X} 3$ & .248 & .104 & .231 & 2.520 & .009 \\
\hline
\end{tabular}

a. Dependent Variable: Y

Berdasarkan Tabel 9 uji hipotesis dilakukan sebagai berikut:

Hipotesis pertama menguji pengaruh $\mathrm{X} 1, \mathrm{X} 2, \mathrm{X} 3$ terhadap $\mathrm{Y}$ berpengaruh positif dan signifikan. 


\section{Pembahasan}

\section{Pengaruh Kepemimpinan Terhadap Kinerja Karyawan Di Hotel D-Max And Convention Lombok Praya Nusa Tenggara Barat}

Hasil uji hipotesis pertama menyatakan bahwa kepemimpinan berpengaruh secara positif dan signifikan terhadap kinerja karyawan di lingkungan kerja hotel D-Max and Convention Lombok Praya Nusa Tenggara Barat, dan membuktikan hipotesis diterima. Dan hasil dari olah data, ditemukan nilai koefisien beta positif sebesar 0,306 dengan nilai signifikansi sebesar 0,032 < 0,05. Hal ini menunjukkan bahwa semakin baik kepemimpinan yang dirasakan karyawan maka akan semakin meningkat juga kinerja karyawannya.

Kemampuan mengambil keputusan merupakan kriteria utama menilai efektivitas kepimpinan seseorang, berarti ada kriteria lain yang dapat dan biasanya digunakan. Berbagai kriteria itu berkisar pada kemampuan seorang pemimipin dalam menjalankan berbagai fungsi-fungsi kepemimpinan. Siagian (2010). Kepemimpinan yang baik adalah kepemimpinan yang memberikan rasa aman dan nyaman bagi karyawannya untuk melakukan aktivitas pekerjaannya yang pada akhirnya mempengaruhi kinerja yang dicapainya.. Dan berikut dimensi dengan jawaban paling tinggi sampai jawaban paling rendah dengan rata-rata mean yang dihasilkan pada setiap dimensi, diantaranya sebagai berikut:

1. Dimensi dengan jawaban paling tinggi adalah dimensi pemimpin sebagai penentu arah yang mendapatkan nilai rata-rata mean sebesar 4.05. Ini menunjukkan bahwa setiap pemimpin yang ada di hotel D-max and Convention mampu memberikan pelayanan yang baik bagi karyawannya, pemimpin yang mampu menyelesaikan pekerjannyanya sesuai target yang telah diberiakn owner hotel D-Max and Convention Lombok. Pada dimensi ini indikator yang menunjukkan mean yang paling rendah dengan nilai mean sebesar 3,82 adalah pada pernyataan pemimpin mampu memberiakn evaluasi yang objektif bagi perbaikan bawahannya .

2. Dimensi dengan jawaban responden tertinggi berikutnya ada pada dimensi pemimpin sebagai wakil dan juru bicara. Ini menunjukkan bahwa perlunya pemimpin yang mampu menjadi mediator dalam menyelesaikan masalah antara bawahan dan manajemen hotel, mendapatkan nilai mean 4.16. merupakan sesuatu yang harus diperhitungkan oleh pemimpin agar pemimpin dapat menjadi penghubung antara pihak karyawan dan manajemen hotel D-Max and Convention Lombok. Pada dimensi ini indikator yang menunjukkan mean yang paling rendah dengan nilai mean sebesar 3,76 adalah pada pernyataan pemimpin selalu mempersatukan setiap permasalahan antar karyawan, pada dimensi ini diaharapakn pemimpin mampu menjadi pemersatu antar karyawan,

3. Dimensi tertinggi berikutnya adalah dimensi pemimpin sebagai komunikator yang mendapatkan nilai rata-rata mean sebesar 4.06. dengan pernyataan sebagai berikut pemimpin selalu mengedepankan kompetensi dan bukan kedekatan secara peribadi. Ini menunjukkan bahwa sebagai pemimpin yang menyadari akan pentingnya kompetensi pada setiap karyawannya. Contoh hotel D-max and convention selalu mengadakan uji kompetensi pada setiap karyawannya ini dilakukan setiap setahun sekali, hal ini menunjukkan perhatian besar seorang pemimpin dan manajemen hotel D-max and convention Lombok kepada karyawannya. Pada dimensi ini indikator yang menunjukkan mean yang paling rendah dengan nilai mean sebesar 3,80 adalah pada pernyataan, pemimpin selalu mengkoordinir keluhan dan menerima masukkan dari karayawanya.

Jadi dengan demikian, ketiga dimensi tersebut merupakan tugas dan tanggung jawab sebagai seorang pemimpin dalam meningkatkan kinerja karyawan hotel D-max and Convention Dan semakin baik seorang pemimpin dalam melaksanakan tugas dan tanggung jawab terhadap karyawannya secara pasti akan berpengaruh terhadap peningkatan kinerja karyawan. 


\section{Pengaruh Motivasi Terhadap Kinerja Karyawan Di Hotel D-Max And Convention Lombok Praya Nusa Tenggara Barat.}

Hasil uji hipotesis kedua menyatakan bahwa motivasi berpengaruh secara positif dan signifikan terhadap kinerja karyawan di lingkungan hotel D-max and Convention lombok, dengan membuktikan hipotesis diterima. Dari hasil dari olah data, ditemukan nilai koefisien beta positif sebesar 0,239 dengan nilai signifikansi sebesar 0,006 $<0,05$. Hal ini menunjukkan bahwa semakin baik motivasi kerja karyawan di hotel $D$-max and Convention Lombok, maka akan semakin meningkat juga kinerja karyawannya.

1. Dimensi pada faktor internal dengan jawaban paling tinggi adalah pada indikator kematangan peribadi yang mendapatkan nilai rata-rata mean sebesar 3.88. Ini menunjukkan bahwa sebagian besar karyawan yang ada di hotel $D$-max and convention Lombok memiliki sifat yang dewasa sebagai karyawan hotel yang mampu menyelesaikan pekerjannya sesuai target yang telah ditentukan oleh manajemen hotel D-max and convention Lombok, contoh pada saat melayani tamu di restaurant setiap karyawan selalu bersikap ramah tamah dan melakukan pekerjaan sesuai dengan SOP yang berlaku di manajemen hotel D-max and convention Lombok. Pada indikator yang menunjukkan mean yang paling rendah dengan nilai mean sebesar 3,87 adalah pada pernyataan, bekerja dengan baik agar segera dipromosikan jabatan baru oleh pemimpin.

2. Dimensi dengan jawaban responden tertinggi berikutnya ada pada indikator keinginan dan harapan. Ini menunjukkan bahwa perlunya sebuah keinginan dan harapan karyawan dalam bekerja, mendapatkan nilai mean 4.08. merupakan sesuatu yang harus diperhitungkan oleh pimpinan supaya terus menjaga konsistensi dari masing-masing karyawan. sebagian besar karyawan juga setuju dengan adanya keinginan dan harapan pada saat bekerja tentu sangat berpengaruh terhadap peningkatan motivasi karyawan dalam bekerja. Pada indikator ini yang menunjukkan mean yang paling rendah dengan nilai mean sebesar 3,90 adalah pada pernyataan menerima uang service dengan jumlah yang sama tanpa membeda-bedakan posisi..

3. Dimensi faktor internal tertinggi berikutnya adalah indikator kebutuhan, yang mendapatkan nilai rata-rata mean sebesar 4.04. ini menunjukkan bahwa sebagian besar karyawan menyadari akan pentingnya kebutuhan yang berupa sandang pangan dan papan karyawan dalam menjalankan aktivitas kerjanya. Pada dimensi ini menjelaskan bahwa karyawan sangat membutuhkan kebutuhan seperti sandang, pangan dan papan terpenuhi. Karena ketiga faktor tersebut merupakan bagian dari kebutuhan dasar bagi setiap karyawan sebelum dan sesudah melaksanakan pekerjaannya. Jadi semakin terpenuhi kebutuhan karyawan, maka akan mempengaruhi peningkatan motivasinya juga. Pada indikator ini yang menunjukkan mean yang paling rendah dengan nilai mean sebesar 3,92 adalah pada pernyataan, merasa puas dengan pelyanan yang sudah didapatkan dari hotel D-max and convention hotel Lombok.

4. Dimensi faktor internal adalah indikatornya adalah status dan tanggung jawab yang mendapatkan nilai rata-rata mean sebesar 4.01.dengan pernyataan sebagai berikut karyawan bertanggung jawab terhadap fasilitas yang ada di hotel D-max and convention Lombok, menunjukkan bahwa bebrapa karyawan memang setuju dengan dilakukan dan diperlukannya status tanggung jawab bagi setiap karyawan yang ada. Contohnya fasilitas hotel D-max and convention Lombok terutama pada penggunaan peralatan dan perlengakapan misalnya peralatan dapur yang kotor hendaknya dibersihkan dan tetap hygienis menandakan rasa tanggung jawab karyawan terhadap fasilitas yang ada di hotel D-max and convention Lombok. Pada indikator ini membahas tentang bagaimana seorang karyawan dapat bertanggung jawab dengan baik pada sesama karyawan dan juga menjalin kerja sama dengan rekan kerja yang di dalam hotel D-max and convention Lombok ataupun di luar lingkungan hotel D-max. Ini tentu mempunyai pengaruh terhadap peningkatan rasa tanggung jawab pada setiap pekerjaannya. Semakin baik status dan tanggung jawab yang dilakukan karyawan, maka akan semakin meningkat juga 
motivasinya. Pada indikator lain yang menunjukkan rata-rata mean yang paling rendah dengan nilai mean sebesar 3,84 adalah pada pernyataan mengikuti kebijakan dan aturanaturan yang ada di hotel D-max and convention Lombok.

5. Dan terakhir adalah, dimensi pada faktor internal dengan jawaban paling rendah ada pada indikator supervisi yang baik yang mendapatkan nilai mean sebesar 3.87. dengan pernyataa sebagai berikut supervisior yang baik bertindak adil dan tidak diskriminatif terhadap masing-masing karyawan ini menunjukkan bahwa terdapat beberapa karyawan yang tidak mendapat respon baik dari pimpinan pada saat melakukan supervisi.

Jadi dengan demikian, kedua dimensi tersebut merupakan pengukuran dari meningkatnya motivasi karyawan dalam bekerja, semakin baik kedua dimensi tersebut dilakukan, maka akan semakin meningkat juga motivasin kinerja karyawannya. Dan semakin meningkat motvasi karyawan dalam bekerja, tentu akan berpengaruh terhadap peningkatan kinerja karyawan.

\section{Pengaruh Lingkungan Kerja Terhadap Kinerja Karyawan Di Hotel D-Max And Convention Lombok Praya Nusa Tenggara Barat.}

Hasil uji hipotesis ketiga menyatakan bahwa lingkungan kerja berpengaruh secara positif dan signifikan terhadap kinerja karyawan di lingkungan hotel D-max and Convention Lombok, dan membuktikan hipotesis diterima. Dari hasil dari olah data, ditemukan nilai koefisien beta positif sebesar 0,231 dengan nilai signifikansi sebesar 0,009 < 0,05. Hal ini menunjukkan bahwa semakin baik lingkungn kerjanya, maka akan semakin meningkat juga kinerja karyawannya.Dan berikut dimensi dengan jawaban paling tinggi sampai jawaban paling rendah dengan rata-rata mean yang dihasilkan pada setiap dimensi, diantaranya sebagai berikut:

1. Dimensi pada lingkungan fisik dengan jawaban paling tinggi adalah pada indikator kebersihan yang mendapatkan nilai rata-rata mean sebesar 4.05 , dengan pernyataan sebagai berikut kebersihan pakaian seragam selalu di utamakan Ini menunjukkan bahwa sebagian besar karyawan yang ada di hotel $D$-max and convention Lombok setuju dengan kebersihan menjadi faktor utama dalam melaksanakan pekerjaan, contohnya section laundry mencuci semua pakaian seragam karyawan yang telah digunakan oleh karyawan. hal ini menunjukkan bahwa pentingnya kebersihan pada saat menjalankan tugas dan pekerjaan masing-masing karyawan hotel D-max and convention Lombok, dengan menjaga kebersihan pakaian, ini akan berpengaruh besar terhadap kenyamanan karyawan maupun pelanggan yang ada di hotel $D$-max and convention Lombok. Pada indikator yang menunjukkan mean yang paling rendah dengan nilai mean sebesar 3,86 adalah pada pernyataan, ventilasi udara yang cukup baik sekitar tempat kerja. Pada dimensi ini karyawan menyadari bahwa pentingnya ventilasi udara pada saat bekerja, sehingga membuat karyawan merasa nyaman dalam bekarja, dan apabila karyawan sudah merasa nyaman dalam bekeraj secara otomatis karyawan akan merasa betah dalam melakukan pekerjaannya sehungga akan berpengaruh positif terhadap kinerjanya

2. Dimensi dengan faktor lingkungan non fisik jawaban responden tertinggi berikutnya ada pada indikator struktur kerja. Ini menunjukkan bahwa perlunya bahwa struktur kerja karyawan dalam bekerja, mendapatkan nilai mean 4.16, pada pernyataan sebagai berikut system kerja pada setiap departemen terjaga dengan baik, merupakan sesuatu yang harus diperhitungkan oleh pihak manajemen hotel, contoh pada setiap departemen yang ada di hotel D-max and convention Lombok memiliki struktur organinsasi yang baik yang dapat menunjang kinerja karyawan artinya setiap karyawan sudah memiliki posisi kerja masing-masing dalam menjalankan tugasnya. Dengan penerapan struktur kerja yang baik ini akan berpengaruh terhadap kinerja karyawan di hotel $D$-max and convention Lombok.. Pada indikator yang lain menunjukkan rata-rata mean yang paling rendah dengan nilai mean sebesar 3,83 adalah pada pernyataan pimpinan sangat memahami dan menghargai setiap ide-ide dari karyawan pada saat meeting. 
Dengan demikian dapat disimpulkan bahwa lingkungan kerja adalah segala sesuatu yang ada di sekitar pada saat bekerja, baik yang berbentuk fisik ataupun non fisik, langsung atau tidak langsung yang dapat mempengaruhi pekerjaannya dalam menjalankan tugasnya,.

\section{Pengaruh Kepemimpinan, Motivasi Dan Lingkungan Kerja Secara Bersama-Sama Terhadap Kinerja Karyawan Di Hotel D-Max And Convention Lombok Praya Nusa Tenggara Barat.}

Motivasi merupakan suatu dorongan, baik yang berasal dari dalam maupun dari luar yang menyebabkan seseorang berbuat sesuatu. Motivasi dalam penelitian ini menjadi variabel yang paling dominan dalam menpengaruhi kinerja karyawan karena motivasi sangat berkaitan dengan kebutuhan secara fisik dan psikologis. Dimensi motivasi dalam penelitian ini adalah faktor internal, yang mana mencakup harga diri dan prestasi, kebutuhan, harapan, tanggung jawab,kepuasan kerja. Komponen-komponen dalam faktor-faktor internal tersebut sangat mempengaruhi kebutuhan karyawan. Dimana seorang karyawan sangat membutuhkan motivasi untuk tetap semangat dalam bekerja secara maksimal. Apabila karyawan menerima uang service dengan jumlah yang tidak sama dan juga dengan membeda-bedakan jabatan yang ada di hotel D-max and convention Lombok, maka akan memicu ketidaknyamanan karyawan dan akan berdampak pada hasil kerja yang buruk.

Lingkungan kerja meruapakan segala sesuatu yang ada disekitar para karyawan yang dapat mempengaruhi kepuasan kerja karyawan dalam melaksanakan pekerjaannya. Lingkungan kerja memegang peranan penting dalam terahadap baik buruknya kualitas hasil kinerja karyawan. Apabila karyawan menyenangi lingkungan kerja dimana mereka bekerja, maka karyawan tersebut akan betah ditempat kerjanya, gembira melakukan aktivitasnya sehingga waktu kerja dipergunakan secara efektif. Sebaliknya lingkungan kerja yang tidak memadai akan dapat menurunkan kinerja karyawan. Manfaat dari lingkungan kerja adalah menciptakan gairah kerja, sehingga produktivitas kerja meningkat. Sementara itu, manfaat yang diperoleh karena bekerja dengan orang-orang yang termotivasi adalah pekerjaan dapat diselesaikan dengan tepat waktu.

Kinerja karyawan merupakan hasil dari tingkat pencapaian tugas maupun tanggung jawab yang diberikan kepada karyawan yang diukur melalui kualitas dan kuantitas dalam suatu jangka waktu tertentu. Kinerja karyawan dipengaruhi oleh dua faktor yaitu faktor kemampuan Secara psikologis, kemampuan karyawan terdiri dari potensi Intelegent Quotient (IQ), serta kemampuan pengetahuan dan keterampilan dan faktor motivasi, motivasi terbentuk dari sikap seorang karyawan dalam menghadapi situasi kerja. Artinya, karyawan harus memiliki sikap mental yang siap, mampu secara fisik, memahami tujuan utama dan target kerja yang akan dicapai, mampu memanfaatkan, dan menciptakan situasi kerja. Dimensi pada kuantitas dari hasil kerja, kualitas pekerjaan yang baik, ketepatan waktu, kemandirian dalam bekerja, inisiatif dalam bekerja tanpa disuruh-suruh dalam melakukan pekerjaannya dan kerja sama yang baik dalam melakukan pekerjaan harus diutamakan dari seluruh departemen yang ada di hotel D-max convention Lombok. Dari hasil Uji F yang didapatkan melalui olah data SPSS, menunjukan bahwa F hitung sebesar 4.367> F table df 3-89 sebanyak 2,71, dengan nilai signifikansi $0,004<0,05$. Maka dapat dikatakan bahwa variabel kepemimpinan, motivasi dan lingkungan kerja, secara bersama-sama berpengaruh terhadap kinerja karyawan di hotel D-max \& convention lombok. Sedangkan untuk Uji $\mathrm{R}^{2}$ diperoleh hasil perhitungan estimasi regresi diperoleh nilai koefisien determinasi (Adjusted $\mathrm{R}$ square) sebesar 0,501 artinya $50,1 \%$ perubahan pada variabel dependen kinerja karyawan (Y) dapat dijelaskan oleh perubahan dalam variabel independen kepemimpinan, motivasi dan lingkungan kerja. Sedangkan sisanya sebesar $49.9 \%$ diterangkan oleh variabel lain yang tidak diajukan atau dijelaskan dalam model penelitian ini. Selanjutnya pada penelitian ini variabel yang paling berpengaruh dominan terhadap kinerja adalah variabel kepemimpinan dengan nilai coeffisien beta sebesar 0.306 dengan tingkat signifikasi 0.032 sampai 0.05. 
Hasil uji $\mathrm{F}$ menunjukkan bahwa variabel kepemimpinan, motivasi dan lingkungan kerja secara bersama-sama berpengaruh positif dan signifikan terhadap kinerja karyawan di hotel D-max and convention Lombok. Dari penjelasan diatas dapat disimpulkan bahwa variabel, kepemimpinan, motivasi dan lingkungan kerja sama-sama memberikan pengaruh terhadap kinerja karyawan. Ketiga variabel ini sangat baik dalam mengukur pengaruh terhadap kinerja. Jadi dengan demikian, ketiga variabel ini dinyatakan positif dan signifikan memberikan pengaruh terhadap kinerja karyawan di di hotel D-Max and Convention Lombok. Adapun untuk mengetahui variabel yang paling dominan memberikan pengaruh terhadap kinerja adalah dengan melihat hasil olah data dari nilai standarized coeficients Beta pada Uji Hipotesis, dan yang paling dominan adalah variabel kepemimpinan karena memiliki nilai Beta 0,306.

\section{KESIMPULAN}

Kepemimpinan, Motivasi kerja dan Lingkungan kerja, berpengaruh signifikan terhadap kinerja karyawan hotel D-Max and Convention Lombok Praya Nusa Tenggara Barat.

a. Kepemimpinan berpengaruh terhadap kinerja karyawan hotel D-Max and Convention Lombok Praya Nusa Tenggara Barat.

b. Motivasi berpengaruh terhadap kinerja karyawan hotel D-Max and Convention Lombok Praya Nusa Tenggara Barat.

c. Lingkungan kerja berpengaruh positif terhadap kinerja karyawan hotel D-Max and Convention Lombok Praya Nusa Tenggara Barat.

\section{DAFTAR PUSTAKA}

Dessler, Gary, 2011. Manajemen Sumber Daya Manusia, Jakarta, Penerbit Indeks.

Haryono, Ph. 2015. Dahsyatnya Pengelolaan Sumber Daya Manusia Dalam Bisnis Perhotelan, Jakarta, Buana Ilmu Popular.

Nawawi, H. Hadari. 2008. Manajemen Sumber Daya Manusia, Yogyakarta Gadjah Mada University Press.

Siagian, Sondang.P. 2006. System Informasi Manajemen, Jakarta, PT. Bumi Aksara.

Sugiyono, 2009. Metode Penelitian bisnis (Pendekatan Kuantitatif, Kualitatif Dan $R \& D$ ), Bandung, CV. Alfabeta. 